\title{
Cultul zeiței Hestia la Milet ŞI ÎN COLONIILE MILESIENE
}

REMUS MIHAI FERARU

\section{REZUMAT:}

Studiul nostru are ca obiect cultul zeiței Hestia la Milet și în coloniile milesiene întemeiate pe coastele Hellespontului,

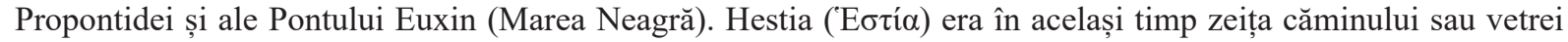
- căminul domestic sau căminul edificiilor publice - și substantivul comun care desemnează acest altar-vatră. Existența zeiței Hestia în panteonul Miletului poate fi presupusă începând din epoca arhaică. La Milet, Hestia este

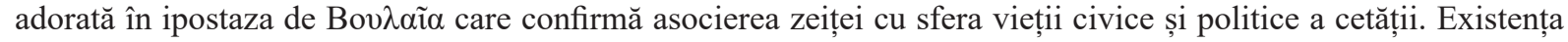
zeiței în panteoanele coloniilor milesiene poate să fie dedusă, cu trei excepții (Cyzic, Sinope, Naukratis) pe baza atestării epigrafice a antroponimelor teoforice derivate de la numele zeiței.

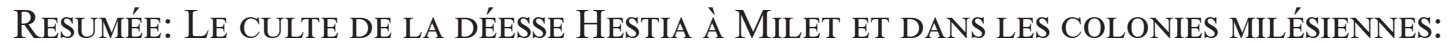

Notre étude porte sur le culte de la déesse Hestia à Milet et dans les colonies milésiennes fondées sur les côtes de

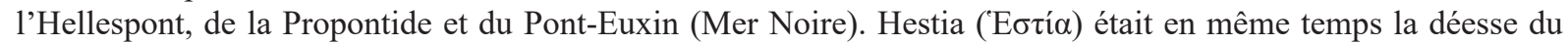
foyer - foyer domestique ou foyer des édifices publics - et le nom commun désignant cet autel-foyer. L'existence de la déesse Hestia dans le panthéon de Milet peut être supposée à partir de l'époque archaïque. À Milet, Hestia est adorée en l'hypostase de Bov $\lambda \alpha$ $\mathbf{\alpha}$ qui confirme l'association de la déesse avec la sphère de la vie civique et politique de la cité. L'existence de la déesse dans les panthéons des colonies milésiennes peut être déduite, à trois exceptions (Cyzique, Sinope et Naucratis), sur la base de l'attestation épigraphique des anthroponymes théophores dérivés du nom de la déesse.

CuvinTE CHEIE: Hestia, cult, epicleză, Milet, colonii milesiene.

MotS CLÉS: Hestia, culte, épiclèse, Milet, colonies milésiennes.

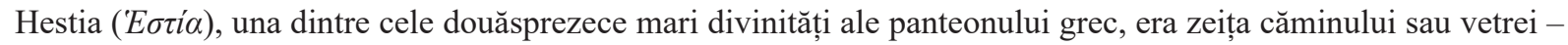
căminul domestic sau căminul edificiilor publice -, mai precis a focului sacru care arde în vatră; în același timp,

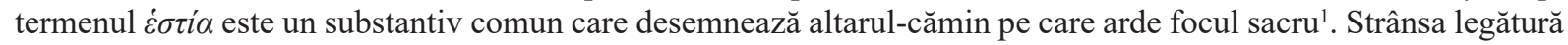
a Hestiei cu vatra constituie rațiunea invocată adesea de către autorii moderni pentru a explica absența miturilor referitoare la zeiță ${ }^{2}$ Într-adevăr, istoria mitică a Hestiei se limitează la nașterea acesteia relatată de către Hesiod ${ }^{3}$, care ne indică faptul că zeiţa era fiica cea mare a lui Cronos și a Rheei, la repudierea Hestiei de către tatăl ei Cronos, care o înghițise îndată după naștere, precum și la propunerile matrimoniale făcute zeiței de către Poseidon și Apollon, toate acestea consemnate în Imnul homeric către Afrodita ${ }^{4}$. Potrivit tradiției mitologice, Hestia a fost cel dintâi copil înghițit de către Cronos; după ce zeița a fost eliberată ultima de către fratele ei Zeus din pântecele tatălui lor Cronos, Poseidon și Apollon au cerut-o de soție, însă Hestia a refuzat propunerea lor, jurând pe capul lui Zeus să rămână veșnic fecioară5. Jurământul de feciorie pe care zeița îl rostește cu această ocazie este motivul

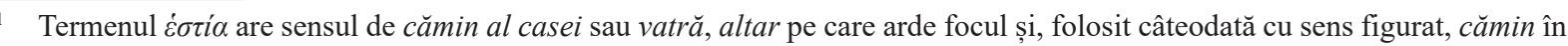
sensul de locuință sau casă. De asemenea, termenul în cauză este folosit pentru a o desemna pe Hestia, zeița vetrei, de altfel o

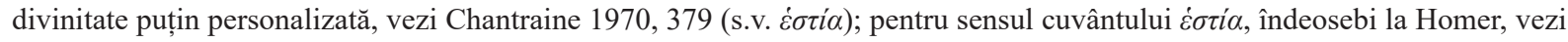
González-García 2010, 376-380. Hestia reprezintă exemplul cel mai clar al transformării unui substantiv comun în numele propriu al unei divinități, vezi Gernet et Boulanger 1970, 206.

2 Personificarea vetrei sacre prin identificarea acesteia cu Hestia explică și caracterul puțin personal al zeiței care a fost deja semnalat de către numeroși autori moderni, vezi De Coulanges 2009, 27-28 (I, 3) și Burkert 1990, 170.

3 Hésiode, Théogonie, (1993), v. 454.

4 Homère, Hymnes. Hymne à Aphrodite, (1936), vv. 22-24.

5 Ibid., vv. 22-28.
} 
pentru care Zeus o recompensează: părintele zeilor o așează în centrul căminului casei, ceea ce îi permite să primească grăsimea ofrandelor, să fie obiectul cinstirilor în toate templele și să fie considerată drept cea mai venerabilă dintre zeițe de către muritori' ${ }^{6}$.

Descrierea Hestiei în poemul Theogonia a lui Hesiod ne lasă să înțelegem că, cultul zeiței exista deja, foarte probabil, în epoca lui Hesiod (secolul al VIII-lea î. Hr.) ${ }^{7}$. Imnul homeric către Afrodita care este posterior cu cel puțin un secol Theogoniei lui Hesiod ${ }^{8}$, constituie a doua tentativă poetică de a-i atribui Hestiei un loc în familia divinităților olimpiene.

Hestia reprezintă « întruchiparea căminului domestic, a flăcării sacre care arde fără încetare în locuințe și în temple, și care le purifică; zeița este venerată în același timp ca protectoare a familiilor, orașelor și coloniilor $\eta^{9}$. Deoarece căminul era considerat centrul vieții domestice, Hestia era zeița ocrotitoare a casei și a vieții de familie; în această calitate, ea întreținea o strânsă relație cu ospitalitatea și convivialitatea care erau valori simbolice asociate zeiței ${ }^{10}$. În același timp, Hestia era considerată şi divinitatea focului sacru care ardea pe altarele templelor; în această din urmă calitate, ea participa la sacrificiile oferite celorlalți zei și primea toate ofrandele primelor roade, indiferent de zeul căruia îi erau destinate ${ }^{11}$.

Întrucât cetatea era considerată o extindere a casei sau a familiei, aceasta avea, la rândul ei, asemenea caselor, un cămin sacru care era plasat de obicei în pritaneu $(\pi \rho v \tau \alpha v \varepsilon i ̃ o v)^{12}$, unde se afla și templul Hestiei. Cu alte cuvinte, prytaneion-ul - sediul magistraților cetăţii (prytanes) - era locul / vatra unde ardea focul sacru al cetății pe altarul zeiței Hestia, lângă care pritanii luau masa în comun, și unde zeița era celebrată în ipostaza de protectoare și izvor al puterii magistraților ${ }^{13}$. Într-un cuvânt, pritaneul este simbolul permanenței cetății, inima simbolică și politică a acesteia. Herodot lasă să se înțeleagă că, atunci când plecau să întemeieze o nouă colonie, coloniștii greci duceau cu ei focul sacru din pritaneul cetății-mamă: „Chiar cei plecați din pritaneul atenienilor, și care se țineau a fi cei mai de seamă dintre ionieni, nu și-au luat cu ei femei când au pornit să întemeieze aceste colonii..."14; aceasta a fost probabil la început o particularitate ioniană ${ }^{15}$. „Noul cămin” simboliza pe vremea aceea două fenomene antitetice în același timp, totuşi reunite sub un același simbol al flăcării: pe de o parte semnifica viața și independența noii cetăți, pe de altă parte constituia expresia continuității și păstrării modelului patriei-mamă. Zeița Hestia este astfel prezentă în mod sistematic în actele fondatoare ale noii colonii printr-un foc inaugural care arată caracterul politic al cultului său ${ }^{16}$.

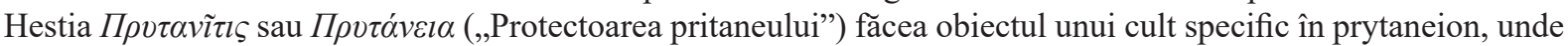
îi erau consacrate ofrande și sacrificii. În Nemeiana XI dedicată pritanului Aristagoras din Tenedos, poetul Pindar menționează locul de cult al Hestiei în incinta sacră a pritaneului; de asemenea, Pindar semnalează „sceptrul spendid" al zeiței ${ }^{17}$, făcând aluzie fără nicio îndoială la statuia Hestiei care ține în mână un sceptru ca atribut. La rândul său, Pausanias menționează un sanctuar consacrat Hestiei la Hermione, în estul Peloponezului1 ${ }^{18}$.

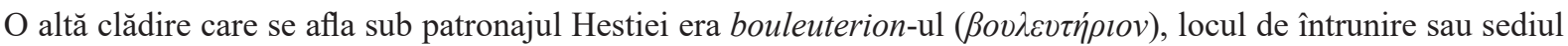

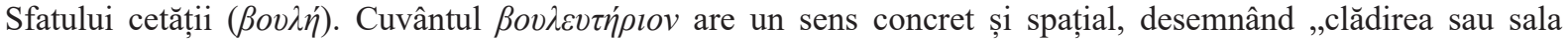
Consiliului cetății, începând din momentul, cel puțin, în care o astfel de sală acoperită este edificată în agora, cu tribuna sa, primele sale bănci rezervate președinților și auditorium-ul său pentru restul buleuților. Sfatul cetăţii (boulé) este condus de colegiul sau comisia temporară a pritanilor care se reunește zilnic în bouleuterion pentru a examina treburile publice. Rolul său constă în particular să delibereze în prealabil asupra tuturor proiectelor de rezoluții care trebuie să fie supuse deliberării ultime a Adunării Poporului, singura autoritate suverană într-o democrație" 19 .

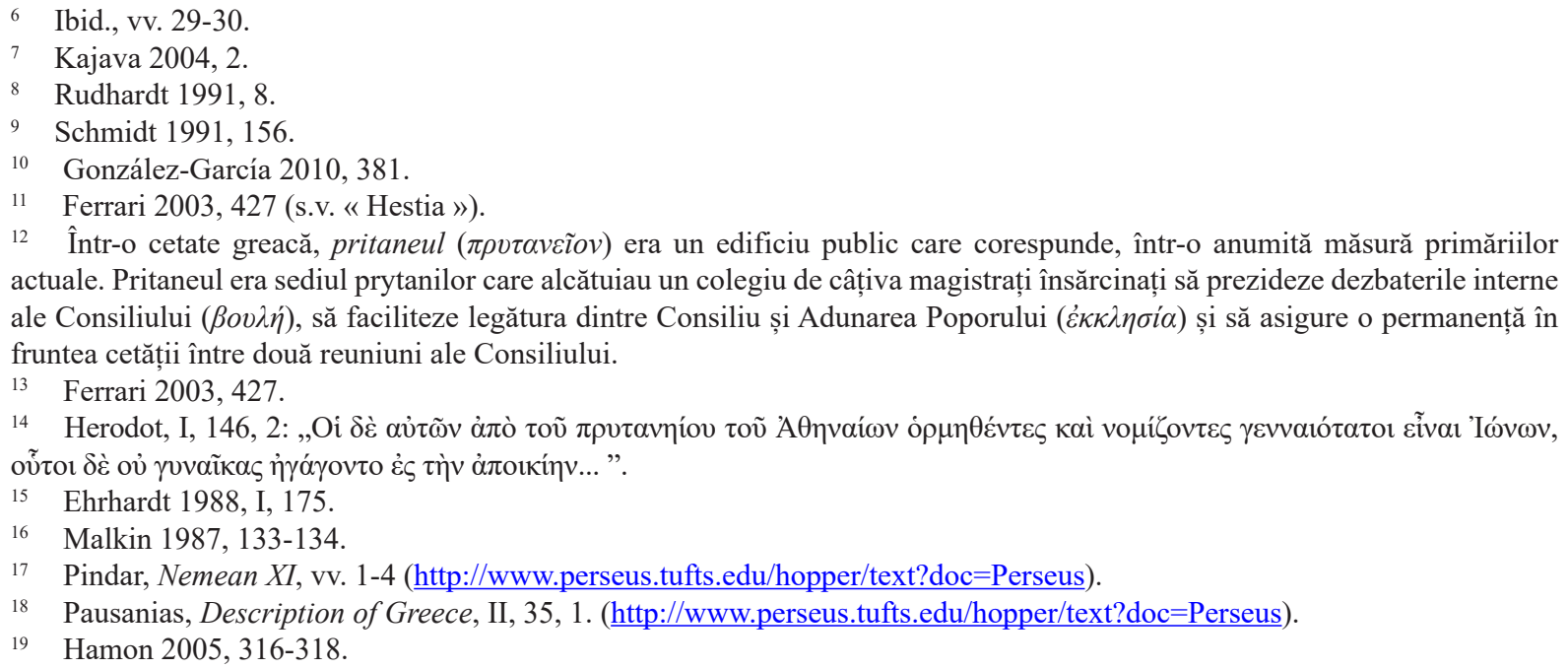


La fel ca orice colegiu de magistrați, Consiliul practică un anumit număr de ritualuri colective a căror destinatari sunt zeii calificați drept boulaioi, și anume zei „ai Consiliului” (boulé), înțeles atât cu sensul de „decizie bună”

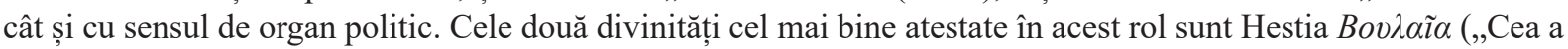
Sfatului / Cea care sfătuiește”) și Zeus Boulaios adesea asociate unul cu celălalt la Atena, Milet, precum și în alte cetăți din Grecia continentală și Asia Mică ${ }^{20}$.

Această lungă introducere servește ca punct de plecare al studiului nostru care își propune să abordeze cultul Hestiei la Milet și în coloniile sale întemeiate pe coastele Hellespontului ${ }^{21}$, Propontidei ${ }^{22}$ și ale Pontului Euxin (Marea Neagră) (Fig. 1,2). Mai precis, studiul nostru are ca obiect cercetarea epiclezelor purtate de către Hestia, a lăcaşurilor de cult și sărbătorilor consacrate zeiței, precum și a ritualurilor aferente acestora.

$\mathrm{Cu}$ toate că se găsea în centrul vieții domestice și publice a polisului grec, Hestia era una dintre zeițele cele mai puțin reprezentative ale acestuia. Așa se explică faptul că numele zeiței și epiclezele care îi sunt asociate sunt atestate rareori și sporadic în documentele epigrafice descoperite în coloniile milesiene. Existența Hestiei în panteoanele Miletului și ale coloniilor sale poate fi dedusă, cu câteva excepții, pe baza atestării epigrafice a antroponimelor teoforice derivate de la numele zeiței.

\section{Cultul Hestiei la Milet}

Existența zeiței Hestia în panteonul Miletului poate fi presupusă încă din epoca arhaică. Această presupunere

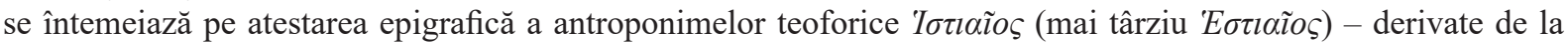
numele Hestiei - în onomastica milesiană ${ }^{23}$.

La Milet, zeița este adorată în ipostaza de Bovגaĩ (,A Sfatului”); acest epitet este asociat cu numele Hestiei în tratatele de isopolitie încheiate de Milet cu cetățile Mylasa (209-208 î. Hr. $)^{24}$ și Herakleia pe Latmos (180 î. Hr. $)^{25}$, precum și în tratatul de sympolitie încheiat de Milet cu cetatea Pidasa (182 î. Hr. $)^{26}$. Într-un alt tratat păstrat fragmentar, încheiat de Milet cu cretanii, Hestia Boulaia este asociată cu Zeus Boulaios ${ }^{27}$. La acestea se adaugă două dedicații consacrate lui Apollon din Didyma şi Hestiei Boulaia, care datează din secolul al II-lea ${ }^{28}$ și respectiv, din secolul I î. Hr. ${ }^{29}$. Nu în ultimul rând, regulamentul de cult al molpoi-lor milesieni, datat la mijlocul secolului al II-lea î. Hr., atestă că magistrații îi consacră sacrificii Hestiei atât la preluarea magistraturii, cât și la ieșirea lor din funcție ${ }^{30}$. Epitetul Boulaia purtat de către Hestia confirmă asocierea zeiței cu sfera vieții civice și politice a cetății; zeița devine o divinitate a Sfatului cetății și inspiră deciziile acestuia. Începând din epoca imperială, Artemis Boulaia se substituie treptat Hestiei Boulaia și va prelua funcțiile acesteia ${ }^{31}$.

\section{Cultul Hestiei în coloniile milesiene din Propontida și de la Pontul Euxin}

Documentele care atestă cultul Hestiei în coloniile Miletului din Propontida și de la Pontul Euxin sunt aproape inexistente. Existența zeiței în panteoanele coloniilor milesiene poate fi dedusă, cu două excepții, pe baza atestării epigrafice a antroponimelor teoforice derivate de la numele zeiței.

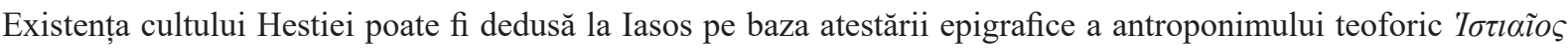
care derivă de la numele « zeiței căminului » $»^{32}$.

\footnotetext{
20 Dovezile literare și epigrafice atestă cultul Hestiei Boulaia la Thera, Pergam, Erythrai, Efes, Cnidos Thasos și Halicarnas, vezi Robert 1924, 179-180; vezi și Robert 1925, 29, n. 1. De asemenea, Hestia Boulaia este atașată de pritaneu.

21 Hellespontul (astăzi strâmtoarea Dardanele) este singura cale navigabilă care leagă Marea Egee de Marea de Marmara (Propontida), vezi Loukopoulou 2004, 900-902.

22 Propontida (astăzi Marea de Marmara) separă Tracia de Asia Mică, incluzând ambele țărmuri ale Mării de Marmara. La sud-vest, strâmtoarea Hellespont separă Propontida de Marea Egee; la nord-est, Propontida este separată de Pontul-Euxin prin strâmtoarea Bosfor. Grecii înșişi au considerat Propontida drept un bazin de intrare, înainte de a pătrunde în Marea Neagră; de aceea, ei au numit-o Пролоvтí ("marea înainte de mare [Pontul-Euxin]"), vezi Avram 2004, 974-976.

Ehrhardt 1988, I, 176; BÉ 1961, 265, nº 846; Bilabel 1920, 96.

Milet I.3, 146 A, r. 21; B, r. 75.

Milet I.3, 150, r. 24, 113.

Milet I.3, 149, r. 59 .

Milet I.3, 37c, r. 43

Milet I.2, 1; 2, r. 2.

Milet I.7, 299, r. 3

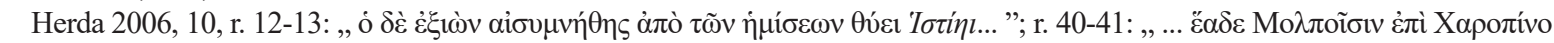

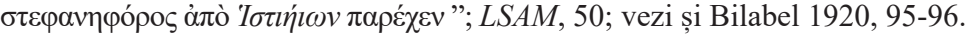

31 Trippé 2009, 284.

32 Bilabel, 1920, 116.
} 
La Cyzic, existența Hestiei poate fi dedusă pe baza atestării epigrafice a antroponimului teoforic Hestiaios $^{33}$. Atestarea prytaneion-ului $i^{34}$ și a bouleuterion-ului cyzician constituie încă o dovadă certă a adorării Hestiei în cetate în ipostaza de Prytaneia și Boulaia. Bouleuterion-ul din Cyzic a preluat foarte probabil tipul arhitectural al bouleuterion-ului milesian care datează din al doilea sfert al secolului al II-lea î. Hr.; edificiul bouleuterion-ului milesian a constituit un prototip în Asia Mică, de vreme ce modelul său se va impune foarte rapid în numeroase cetăți, începând din Propontida până în Pisidia ${ }^{35}$.

La Sinope, Hestia este adorată cu epicleza $\Pi \rho v \theta \alpha v \varepsilon i \alpha$ care scoate în evidență legătura zeiței cu prytaneion-ul și funcția acesteia de protectoare a prytanilor și a cetății; aceștia din urmă îi consacră o dedicație Hestiei Prytaneia: « Pe vremea când Epidemos, fiul lui Epielpes îndeplinea funcția de nomophylax, prytanii din luna Panemos (i-au consacrat această dedicație) Hestiei Prytaneia $»^{36}$. Hestia Prytaneia adorată la Sinope este una și aceeași zeiță cu Hestia menționată în regulamentul molpoi-lor milesieni, datat la mijlocul secolului al II-lea î. Hr.. Cu alte cuvinte, cetatea Sinope a preluat cultul Hestiei Prytaneia din metropola ei Milet ${ }^{37}$. În egală măsură, existența Hestiei în

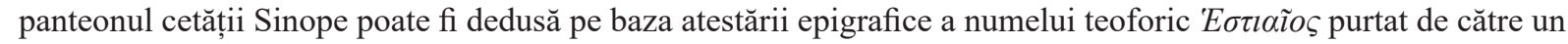

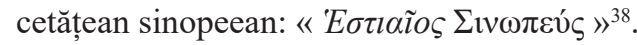

Existenţa Hestiei în panteoanele Apolloniei Pontice, Odessosului, Dionysopolisului, Tomisului, Istrosului, Olbiei,

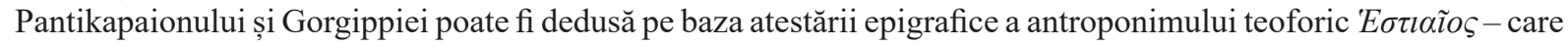
derivă de la numele zeiței - în onomastica acestor colonii milesiene ${ }^{39}$. De altfel, Hestiaios este un nume teoforic foarte frecvent întâlnit în cetățile ioniene fără a se limita doar la acestea; el este atestat și pe monede descoperite la Tomis, Odessos, Athena, Chios, Clazomene, Halicarnas, Iasos, Myndos, Cyzic și Seleucia din Cilicia ${ }^{40}$.

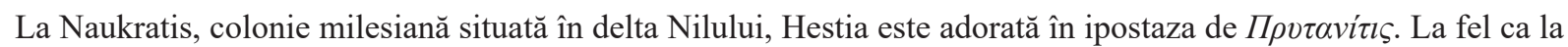
Sinope, această epicleză relevă legătura zeiței cu prytaneion-ul și funcția acesteia de protectoare a prytanilor și a cetății. Potrivit lui Hermias din Methymne citat de către Athenaios, naucratiții oficiau cultul Hestiei Prytanitis în prytaneion-ul cetății care este atestat încă din secolul al IV-lea î. Hr.; aceștia celebrau aniversarea zeiței în fiecare an, fără îndoială pentru a sărbători în mod simbolic întemeierea cetății ${ }^{41}$.

\section{Concluzii}

În ciuda numărului redus al dovezilor referitoare la cultul Hestiei, se poate presupune că zeița fusese adorată în coloniile milesiene încă de la întemeierea acestora. De altfel, Herodot lasă să se înțeleagă că, atunci când coloniștii greci plecau să întemeieze o apoikia, duceau cu ei în noua colonie focul sacru din prytaneion-ul cetătiii-mamă $\breve{a}^{42}$. Așadar, pornind de la informația furnizată de către Herodot și confirmată de către Athenaios pentru colonia milesiană Naukratis, se poate admite că coloniile milesiene au moștenit cultul Hestiei din metropola lor Milet. Cultul Hestiei avea în același timp un caracter civic și politic precum atestă epiclezele purtate de către zeiță (Boulaia, Prytaneia, Prytanitis) care era adorată în ipostaza de divinitate protectoare a prytanilor și în general a celorlalți magistrați ai cetății.

\footnotetext{
33 Ehrhardt 1988, I, 176; II, 480, n. 944.

34 Ibid., I, 195; II, 501, n. 1128. Prytaneion-ul cyzician este atestat într-o inscripție care datează din secolul al VI-lea î. Hr., vezi Bilabel 1920, 116.

35 Hamon 2005, 323

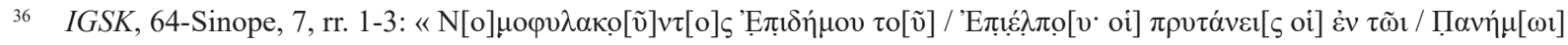

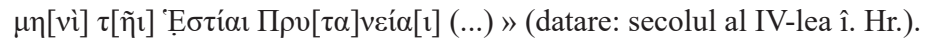

37 Herda 2006, 143, n. 1006.

$38 I G$ VII, 414, r. 25 (datare: mijlocul secolului al IV-lea î. Hr.). Numele Hestiaios apare şi pe amforele ștampilate de la Sinope, vezi, Canarache 1957, 400

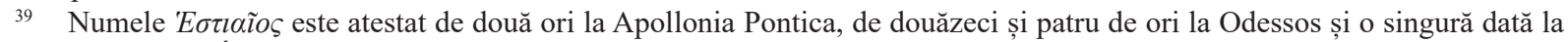

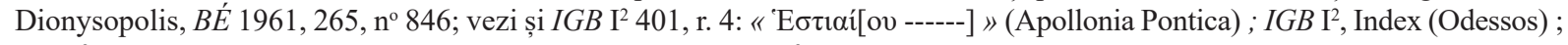

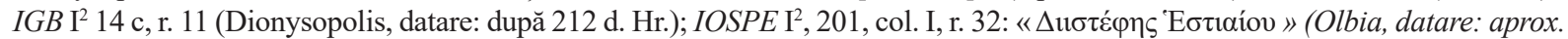

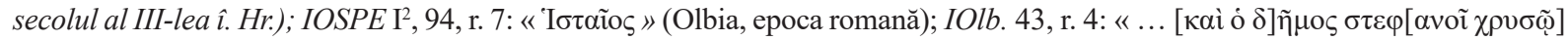

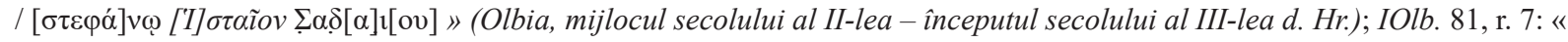

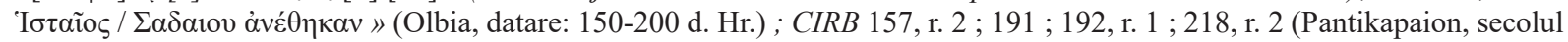

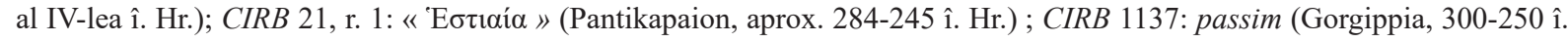
Hr.); vezi și Ehrhardt 1988, II, 481, notele 947-954 ; Bilabel 1920, 116.

$40 \quad B E ́$ 1961, 265, no 846

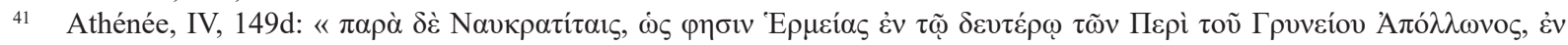

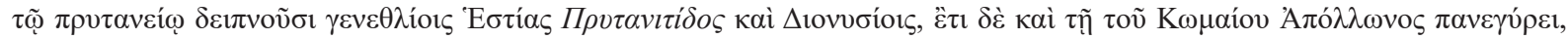

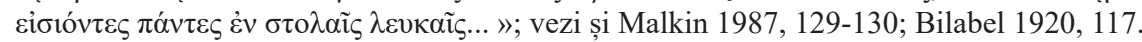

42 Herodot, I, 146, 2.
} 


\section{LISTA ABREVIERILOR BIBLIOGRAFICE}

$B E^{\prime}$

$C I R B$

$I G B \mathrm{I}^{2}$

IGSK, 64-Sinope

IOlb

IOSPE $\mathrm{I}^{2}$

LSAM

Milet I.3

$R E G$
Bulletin Épigraphique al revistei Revue des Études Grecques, Paris, (1888-). Corpus Inscriptionum Regni Bosporani (Korpus Bosporskikh nadpisej), (ed. V. V. Struve), Moscova-Leningrad, 1965.

Inscriptiones Graecae in Bulgaria repertae, vol. I²: Inscriptiones orae Ponti Euxini, (ed. Georgi Mihailov). Sofia, 1970.

Inschriften griechischer Städte aus Kleinasien, 64: The Inscriptions of Sinope, Part I, (ed. D. H. French), Bonn, 2004.

Inscriptiones Olbiae (Nadpisi Ol'vii) (1917-1965), (ed. T. N. Knipovič, E. I. Levi), Leningrad, 1968.

Inscriptiones antiquae orae septentrionalis Ponti Euxini Graecae et latinae, (ed. Basilius Latyšev), I': Inscriptiones Tyrae, Olbiae, Chersonesi Tauricae, Sankt Petersburg, 1916.

Lois sacrées de l'Asie Mineure, ed. F. Sokolowski, Paris, 1955.

Milet I. Ergebnisse der Ausgrabungen und Untersuchungen seit dem Jahr 1899, Heft. III: Das Delphinion von Milet, von G. Kawerau und A. Rehm, Berlin, 1914. Revue des Études Grecques, Paris, (1888-).

\section{BIBLIOGRAFIE}

Avram, A. 2004. The Propontic Coast of Asia Minor, in: M. H. Hansen, T. H. Nielsen, (eds), An Inventory of Archaic and Classical Poleis: 974-999. New York: Oxford University Press Inc..

Bilabel, F. 1920. Die ionische Kolonisation. Untersuchungen über die Gründungen der Ioner, deren staatliche und kultliche Organisation und Beziehungen zu den Mutterstädten, Philologus, Supplementband XIV, Heft 1. Leipzig: Dieterich'sche Verlagsbuchhandlung M. B. H..

Burkert. W. 1996. Greek religion, Archaic and Classical. Translated by John Raffan. London: Blackwell.

Canarache, V. 1957. Importul amforelor ștampilate la Istria, București: Editura Academiei.

Chantraine, P. 1970. Dictionnaire étimologique de la langue grecque, II (E-K). Paris: Éditions Klincksieck.

De Coulanges. F. 2009. La Cité antique. Étude sur le culte, le droit, les institutions de la Grèce et de Rome. Cambridge: Cambridges University Press.

Ehrhardt, N. 1983. Milet und seine Kolonien. Vergleichende Untersuchung der kultischen und politischen Einrichtungen, Europäische Hochschulschriften, Reihe 3, 206. Frankfurt am Main, Bern, New-York: Peter Lang.

Ferrari, A. 2003. Dicţionar de mitologie greacă şi romană. traducere de Dragoş Cojocaru, Emanuela Stoleriu, Dana Zămosteanu. Iaşi: Editura Polirom.

González-García, F. J. 2010. Hestia chez Homère: foyer ou déesse?, în: D. Auger \& Ch. Delattre (eds.), Mythe et fiction: 369-382. Paris: Presses Universitaires de Paris Ouest.

Hamon, P. 2005. Rites et sacrifices celébrés dans le conseil. Remarques sur les cultes du bouleutèrion et leur évolution à l'époque hellénistique. Topoi, 12-13/1: 315-332.

Herda, A. 2006. Der Apollon-Delphinios-Kult in Milet und die Neujahrsprozession nach Didyma. Ein neuer Kommentar der sog. Molpoi-Satzung, (Milesische Forschungen 4) Mainz am Rhein: Verlag Philipp von Zabern.

Herodot, Istorii. Cartea I: Clio. studiu introductiv, traducere, notițe istorice şi note de Adelina Piatkowski, București: Editura Teora, 1999.

Hésiode, Théogonie; Les Travaux et les Jours; Le bouclier. texte établi et traduit par Paul Mazon, Paris: Les Belles Lettres, 1993.

Homère. Hymnes. Hymne à Aphrodite. texte établi et traduit par Jean Humbert. Paris: Les Belles Lettres, 1936.

Kajava, M. 2004. Hestia, Hearthe, Goddess, and Cult. Harvard Studies in Classical Philology, vol. 102, 2004: 1-20, DOI: https://doi.org/10.2307/4150030.

Loukopoulou, L. 2004. Thracian Chersonesos, in: M. H. Hansen, T. H. Nielsen, (eds), An Inventory of Archaic and Classical Poleis: 900-911. New York: Oxford University Press Inc.. 
Malkin, I. 1987. Religion and Colonization in Ancient Greece, (Studies in Greek and Roman Religion, 3). Leiden: Brill.

Pausanias, Description of Greece accesat în 13.08.2021. http://www.perseus.tufts.edu/hopper/text?doc=Perseus.

Pindar, Nemean XI, accesat în 13.08.2021. http://www.perseus.tufts.edu/hopper/text?doc=Perseus.

Robert, L. 1924. Epigraphica. REG 37, no. 170/171, 1924: 179-181.

Robert, L. 1925. Lesbiaca. REG 38, no. 174, 1925: 29-43.

Robu, A. 2012. Les établissements mégariens de la Propontide et du Pont-Euxin: réseaux, solidarités et liens institutionnels, în: Laurianne Martinez-Sève (ed.), Les diasporas grecques du VIII à la fin du III siècle av. J.-C. (Pallas No. 89): 181-195.

Rudhardt, J. 1991. L'hymne homérique à Aphrodite: essai d'interpretation. Museum Helveticum : schweizerische Zeitschrift für klassische Altertumswissenschaft, 48, 1991/1: 8-20, DOI: http://doi.org/10.5169/seals-37691.

Schmidt, J. 1991. Dictionnaire de la mythologie grecque et romaine. Paris: Larousse.

Trippé, N. 2009. Les épiclèses d'Artémis à Milet-Didymes: quelles offrandes et quels donateurs pour les différents facettes de la déesse ?, în: Clarisse Prêtre (dir.), La donatrice, l'offrande et la déesse, (Kernos supplément 23): 273285. Liège: Centre international d'étude de la religion grecque antique (CIERGA).

REMUS MIHAI FERARU

Universitatea de Vest din Timișoara remusferaru@yahoo.fr 


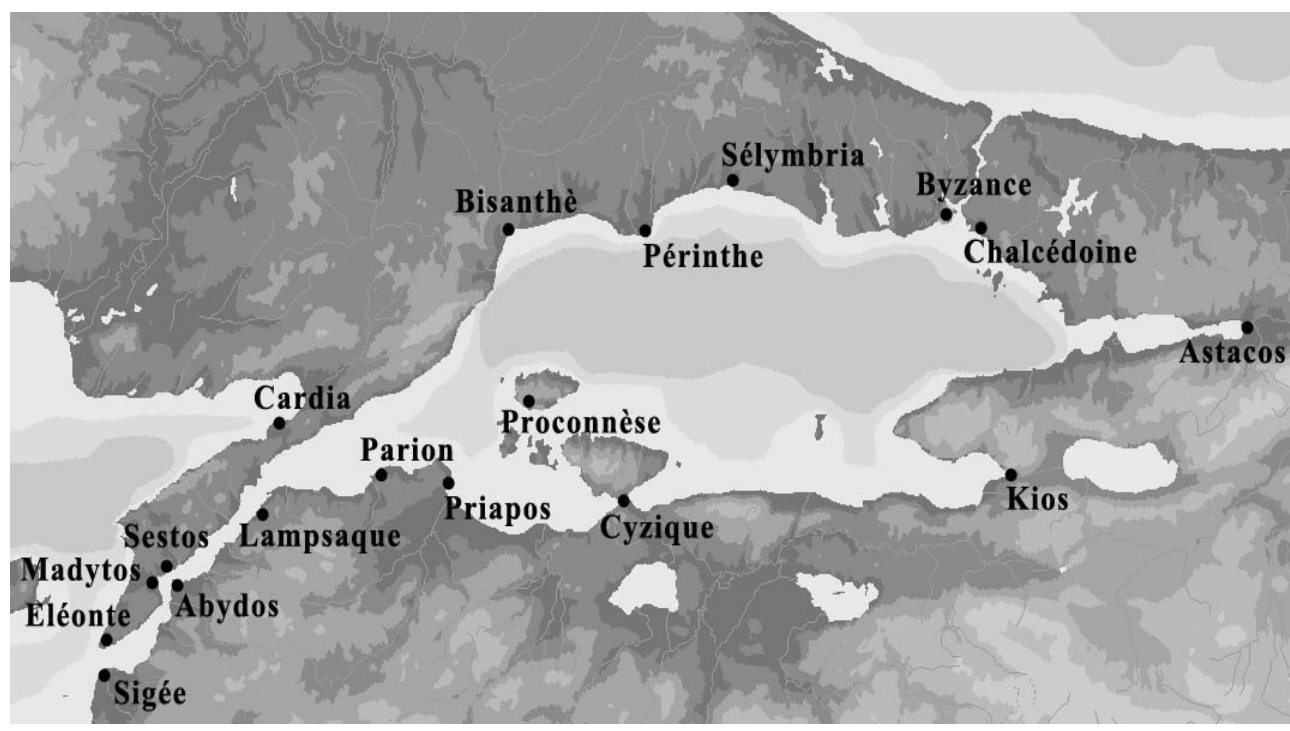

Fig. 1. Harta generală a cetăților grecești de pe țărmurile Hellespontului și ale Propontidei (apud Robu 2012, 195).

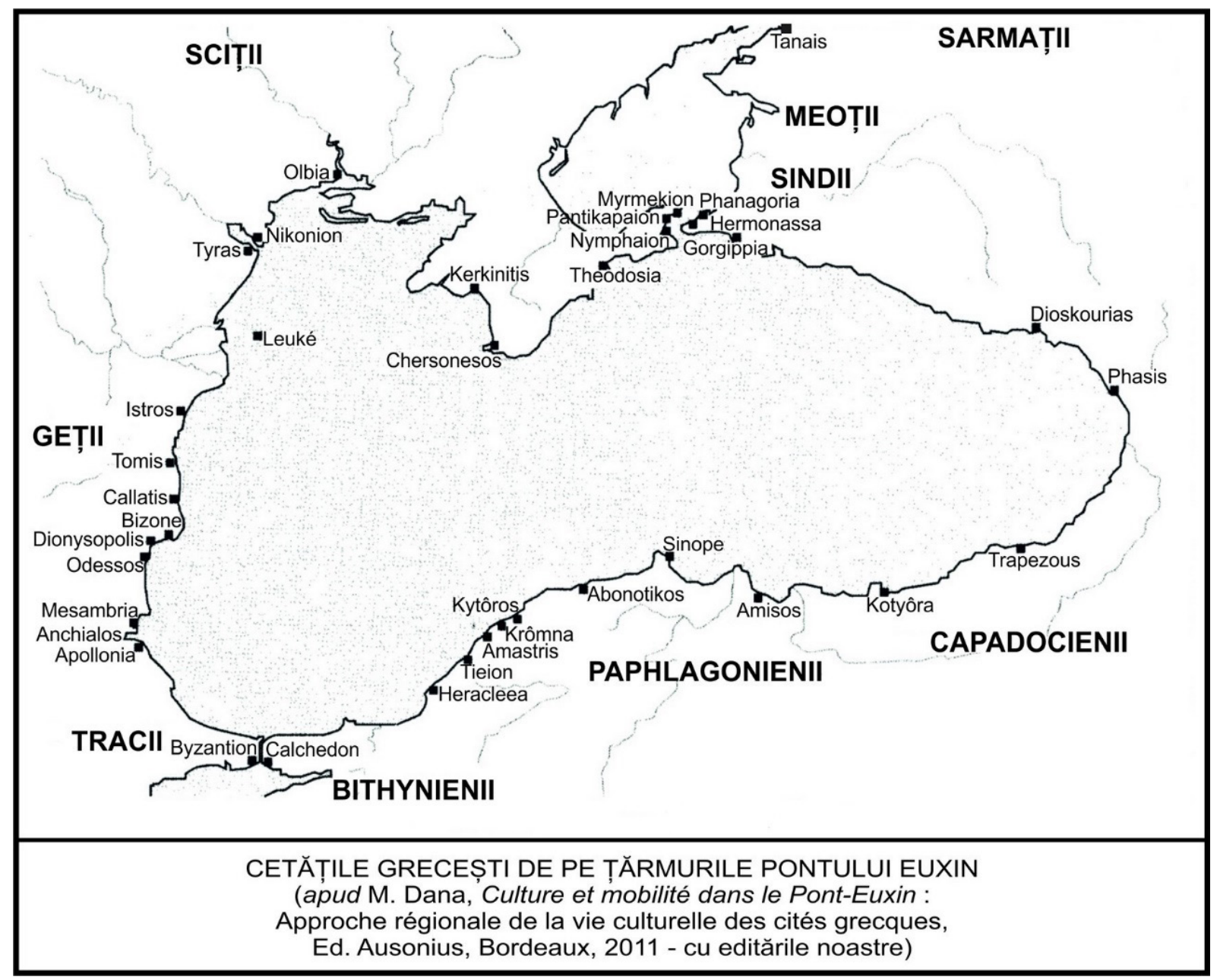

Fig. 2. Harta generală a cetăților grecești de pe țărmurile Pontului Euxin (apud Dana 2011 - cu editările noastre) 
